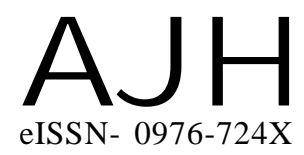

Article history :

Received : 02.02.2016

Revised : 05.05.2016

Accepted : 14.05.2016

Members of the Research Forum

Associated Authors:

${ }^{1}$ Department of Horticulture, Faculty

of Agriculture, Annamalai

University, Annamalai Nagar,

CHIDAMBARAM (T.N.) INDIA

Author for correspondence :

J.P.SAJITHA

Department of Vegetable Crops,

Horticultural College and Research

Institute, Tamil Nadu Agricultural

University, COIMBATORE (T.N.)

INDIA
THEASIAN JOURNALOF HORTICULTURE

Volume 11 | Issue 1 | June, 2016 | 172-175

Visit us -www.researchjournal.co.in

\section{Response of garden bean to organic manures and biofertilizers on growth, yield and quality attributes}

\section{J.P. SAJITHA AND K. HARIPRIYA ${ }^{\mathbf{1}}$}

ABSTRACT : The response of garden bean variety Konkan Bushan to organic manures along with biofertilisers as a substitute to chemical fertilizers was studied at olericulture unit, Department of Horticulture, Faculty of Agriculture, Annamali University. Among the treatments tested inoculation of Rhizobium and Vesicular arbuscular mycorrihae (VAM) along with vermicompost and vermiwash yielded better than uninoculated and controlled treatments. As a result of increased nutrient uptake, nodulation and biological nitrogen fixation of Rhizobium, colonization of VAM and supplementation of nutrients through vermiwash and vermicompost derived from vegetable waste was found to be superior. Earliness in flowering was observed in the treatment Pressmud based vermicompost, VAM, Rhizobium along with vermiwash. The treatment supplied with Rhizobium and VAM along with flower waste vermicompost and spraying of vermiwash reigstered highest protein content. The treatment which received with pressmud based vermicompost, biofertilizer and vermiwash recorded highest fibre content. These result indicate that the garden bean being responds very well for inoculation of Rhizobium, VAM and vermicompost and its wash for providing all necessary nutrients in available form.

KEY WORDS : Garden bean, Rhizobium, VAM, Vermiwash, Pressmud, Vegetable waste based vermicompost

HOW TO CITE THIS ARTICLE : Sajitha, J.P. and Haripriya, K. (2016). Response of garden bean to organic manures and biofertilizers on growth, yield and quality attributes. Asian J. Hort., 11(1) : 172-175, DOI : 10.15740/HAS/TAJH/11.1/172-175. 